\title{
Peningkatan Hasil Belajar Melalui Model Kooperatif Tipe NHT pada Mata Pelajaran IPA
}

\section{Nuro Alfain Nova*}

Program Studi Pendidikan Guru Sekolah Dasar Fakultas Ilmu Pendidikan Universitas PGRI Semarang

\section{A R T I C L E I N F O}

Article history:

Received 20 August 2018

Received in revised form

9 September 2018

Accepted 15 October 2018

Available online 29

November 2018

Kata Kunci:

Numbered Head Together,

Hasil Belajar, IPA

Keywords:

Numbered Head Together,

Learning Outcomes, Science.

\section{A B S T R A K}

Tujuan penelitian ini adalah untuk mengetahui peningkatan hasil belajar siswa kelas III B SD Negeri Kebonbatur 02 Mranggen pada mata pelajaran IPA dengan menggunakan model kooperatif tipe NHT. Jenis penelitian yang digunakan adalah penelitian tindakan kelas yang dilaksanakan dalam dua siklus. Setiap siklus terdiri dari tahap perencanaan, pelaksanaan, pengamatan, dan refleksi. Subjek dalam penelitian ini adalah siswa kelas III.B tahun 2017/2018 yang berjumlah 34 siswa yang terdiri dari 18 siswa laki-laki dan 16 siswa perempuan, serta guru mata pelajaran IPA. Berdasarkan analisis data hasil penelitian, diperoleh hasil pengamatan terhadap persentase aktivitas belajar siswa pada saat pembelajaran mengalami peningkatan dari siklus I sebesar $72,52 \%$ menjadi $81,71 \%$ pada siklus II. Demikian pula performansi guru pada siklus I mencapai 82,5 dan meningkat menjadi 91,3 pada siklus II. Sedangkan, persentase ketuntasan hasil belajar siswa pada siklus I mencapai $58,82 \%$ dengan nilai rata-rata kelas sebesar 73,56 dan pada siklus II ketuntasan belajar siswa meningkat menjadi $94,12 \%$ dengan nilai rata-rata kelas sebesar 79,5 . Berdasarkan hasil penelitian di atas, dapat disimpulkan bahwa melalui penerapan model kooperatif tipe NHT telah berhasil meningkatkan Aktivitas dan Hasil Belajar mata pelajaran IPA materi kenampakan permukaan bumi siswa kelas III.B SD Negeri Kebonbatur 02 Mranggen. Saran untuk semua pihak terkait diharapkan dapat mengembangkan penelitian ini tentang Model Kooperatif Tipe NHT, sehingga diharapkan dapat memperoleh temuan-temuan baru yang bermanfaat demi mewujudkan kualitas pendidikan yang lebih baik.

\section{A B S T R A C T}

The purpose of this study is to determine the increase in learning outcomes of students in class III B of SD Negeri Kebonbatur 02 Mranggen on science subjects using the cooperative type NHT model. The type of research used is classroom action research conducted in two cycles. Each cycle consists of the stages of planning, implementation, observation, and reflection. The subjects in this study were class III.B students in 2017/2018, which 34 students consisting of 18 male students and 16 female students, as well as science subject teachers. Based on the analysis of research data, the results of the observation of the percentage of student learning activities at the time of learning increased from the first cycle of $72.52 \%$ to $81.71 \%$ in the second cycle. Similarly, the teacher's performance in the first cycle reached 82.5 and increased to 91.3 in the second cycle. Meanwhile, the percentage of completeness of student learning outcomes in the first cycle reached $58.82 \%$ with a class average value of 73.56 and in cycle II student learning completeness increased to $94.12 \%$ with a class average value of 79.5. Based on the results of the above research, it can be concluded that through the application of the cooperative model NHT type has succeeded in increasing the Activity and Results of Learning Science subjects for the topic of material: earth's surface in class III.B. The researcher suggests all relevant parties to develop the research about the Cooperative Type NHT Model, so it can obtain new findings that are useful for realizing better quality of education.

Copyright () Universitas Pendidikan Ganesha. All rights reserved. 


\section{Pendahuluan}

Pendidikan merupakan suatu usaha agar manusia dapat mengembangkan potensi yang dimilikinya melalui proses pembelajaran maupun cara lain yang dikenal dan diakui oleh masyarakat. Setiap manusia memiliki hak yang sama untuk mendapatkan pendidikan yang layak. Pendidikan merupakan suatu usaha untuk mencapai dan mengarahkan seseorang dalam menuju kedewasaan dengan memberikan berbagi ilmu pengetahuan, melatih berbagai keterampilan, penanaman nilai-nilai yang baik, serta sikap yang layak dan wajar (Kurniasari, 2014). Pendidikan sangat penting bagi kehidupan. Melalui pendidikan, manusia dapat memperoleh pengalaman yang bermakna bagi dirinya, masyarakat maupun pembangunan bangsa.

Menurut Undang-Undang RI Nomor 20 Tahun 2003 tentang Sistem Pendidikan Nasional Bab I Pasal 1 menyatakan bahwa pendidikan adalah usahasadar dan terencana untuk mewujudkan suasana belajar dan proses pembelajaran yang kondusif agar siswa secara aktif dapat mengembangkan potensi dirinya untuk memiliki kekuatan spiritual keagamaan, pengendalian diri, kepribadian, kecerdasan, akhlak mulia, serta keterampilan yang diperlukan dirinya, masyarakat, bangsa dan negara.

Pembelajaran Ilmu Pengetahuan Alam (IPA) menurut hakikatnya adalah untuk mempelajari gejalagejala melalui serangkaian proses yang dikenal dengan proses ilmiah yang dibangun atas dasar sikap ilmiah dan hasilnya terwujud sebagai produk ilmiah yang tersusun atas tiga komponen terpenting berupa konsep, prinsip, dan teori yang berlaku secara universal (Trianto, 2010: 141). Mutu pembelajaran bidang studi IPA sangat ditentukan oleh bagaimana cara guru mengelola pembelajaran IPA itu sendiri. Beranjak dari sini, maka dapat dirumuskan bahwa mutu pembelajaran IPA di sekolah dasar sangat menentukan mutu siswa dalam penguasaan mata pelajaran IPA, dan pengembangan serta pemanfaatannya di kemudian hari. Mata pelajaran IPA berguna untuk pengembangan pengetahuan keterampilan dan sikap ilmiah pada siswa serta memupuk rasa mencintai dan menghargai pencipta-Nya. Melihat hakikat yang demikian itu, maka pendekatan dalam belajar yang tepat adalah pendekatan keterampilan proses.

Suatu proses pembelajaran akan menghasilkan kondisi di mana individu dalam hal ini siswa dan guru, siswa dengan siswa atau interaksi yang kompleks sekalipun pasti akan ditemukan suatu proses komunikasi. Landasan komunikasi ini akan banyak memberikan warna dalam bentuk pendekatan, model, metode dan strategi pembelajaran, serta pola inovasi pembelajaran. Seorang guru harus mampu melakukan variasi komunikasi dalam proses pembelajaran dengan memperhatikan komponen pembelajaran lainnya, khususnya peserta didik dan model pembelajaran yang digunakan. Keberhasilan proses pembelajaran dapat dilihat dari hasil belajar yang diperoleh siswa. Hasil belajar yang baik dapat dicapai melalui metode mengajar yang digunakan, motivasi belajar, aktivitas dan perhatian siswa yang tinggi.

Berdasarkan kajian kebijakan kurikulum IPA yang dilakukan Depdiknas pada tahun 2007, menunjukkan bahwa masih banyak permasalahan pelaksanaan standar isi pada mata pelajaran IPA. Permasalahan tersebut antara lain metode pembelajaran terlalu berorientasi pada guru (teacher centered), kurangnya penggunaan media dalam pembelajaran serta belum menggunakan lingkungan belajar sebagai sumber belajar kontekstual. Sehingga mengakibatkan pembelajaran kurang terlaksana secara optimal, cenderung mengabaikan hak-hak dan kebutuhan serta pertumbuhan dan perkembangan siswa.

Permasalahan pembelajaran IPA tersebut di atas, merupakan gambaran yang terjadi di kelas III B SD Negeri Kebonbatur 02 Mranggen. Bertolak pada refleksi awal dengan tim kolaborasi, dinyatakan bahwa kualitas pembelajaran IPA masih belum optimal. Guru hanya menggunakan metode ceramah, pembelajaran masih berpusat pada guru (teacher centered), penggunaan media pembelajaran serta sumber belajar masih kurang, kurangnya variasi dalam pembelajaran, sehingga siswa kurang aktif, kurang merespon interaksi dari guru, cepat merasa bosan dan terkadang ditemui siswa yang berbicara sendiri dengan temannya.

Data hasil observasi dan evaluasi muatan pembelajaran IPA pada materi energi dan perubahannya siswa kelas III B SD Negeri Kebonbatur 02 Mranggen tahun pelajaran 2017/2018 yang berjumlah 39 siswa hanya 21 siswa $(54,29 \%)$ yang mendapatkan nilai rata-rata di atas Kriteria Ketuntasan Minimal (KKM) yaitu 65,sedangkan sisanya 17 siswa $(45,71 \%)$ nilai rata-ratanya di bawah KKM (65). Bertolak pada data hasil belajar dan proses KBM muatan pembelajaran IPA di atas, maka dapat ditarik kesimpulan bahwa pembelajaran IPA di kelas III B SD Negeri Kebonbatur 02 Mranggen perlu ditingkatkan lagi hasil belajarnya. Adapun cara meningkatkan hasil pembelajaran IPA tersebut ialah dengan mencari solusi/alternatif tindakan yang tepat, agar siswa lebih antusias dan aktif dalam mengikuti pembelajaran serta memahami materi yang disampaikan guru.

Usaha-usaha guru dalam membelajarkan siswa merupakan bagian yang sangat penting dalam mencapai keberhasilan tujuan pembelajaran yang sudah direncanakan. Guru harus bisa menciptakan 
pembelajaran yang menarik dan dapat dipahami siswa dengan baik sehingga IPA menjadi mata pelajaran yang diminati dan dikuasai oleh siswa.

Penggunaan model pembelajaran yang tepat diharapkan mampu meningkatkan proses dan hasil belajar siswa. Dalam proses pembelajaran,masih sering dijumpai adanya kecenderungan siswa untuk tidak mau bertanya meskipun belum paham akan materi yang disampaikan oleh guru. Ketika guru bertanya tentang materi yang belum dipahami oleh siswa,siswa hanya diam. Maka, dalam proses belajar mengajar diperlukan model pembelajaran yang tepat untuk mencapai tujuan belajar yang telah ditentukan.

Model pembelajaran Numbered Heads Together (NHT) merupakan salah satu tipe dari pembelajaran kooperatif. Daryanto dan Muljo Rahardjo (2012: 245) menyatakan bahwa pada umumnya NHT digunakan untuk melibatkan siswa dalam penguatan pemahaman pembelajaran atau mengecek pemahaman siswa terhadap materi. Dalam pembelajaran dengan model NHT, siswa akan terpacu untuk menumbuhkan kreatifitas dan meningkatkan motivasi belajar yang akan membawa pengaruh positif yaitu meningkatkan hasil belajar siswa pada mata pelajaran IPA. Pembelajaran dengan model NHT juga memberikan kesempatan bagi siswa untuk aktif dan membuat suasana belajar menjadi menarik, menantang dan menyenangkan, sehingga NHT akan sesuai jika diterapkan dalam pembelajaran IPA. Model pembelajaran kooperatif Tipe NHT memiliki kelebihan diantaranya dapat memupuk hasil belajar siswa, mampu memperdalam pamahaman siswa, menyenangkan siswa dalam belajar, mengembangkan sikap positif siswa dan sikap kepemimpinan siswa serta mengembangkan rasa ingin tahu siswa (Yudiastuti, 2014). Pembelajaran NHT merupakan tipe pembelajaran yang dirancang untuk mempengaruhi pola interaksi siswa dan memiliki tujuan untuk meningkatkan semangat semangat kerjasama dalam kelompok serta memberikan kesempatan kepada siswa untuk saling membagi ide-ide dan mendiskusikan jawaban yang paling tepat. Lorina (2012:9).

Dengan menggunakan model pembelajaran NHT, siswa dapat bertukar pikiran dengan teman sekelompoknya, siswa mempunyai kesiapan yang sama untuk menjawab soal yang diberikan dari guru, siswa juga lebih senang dalam mengikuti pembelajaran karena setiap siswa memakai nomor kepala dan memperhatikan media yang menjadikan lebih bersemangat dan menarik perhatian. Selain itu, NHT juga memiliki beberapa kelebihan, yaitu meningkatkan kerjasama dalam kelompok, karena setiap siswa dapat menyumbangkan ide-ide mereka dan mempertimbangkan jawaban yang paling tepat. NHT juga dapat diterapkan dalam semua mata pelajaran dan untuk semua tingkatan usia siswa (Lie, 2005: 59).

Manfaat dari penelitian ini ialah untuk meningkatkan hasil pembelajaran IPA pada materi kenampakan permukaan bumi pada siswa kelas III B SD Negeri Kebonatur 02 Mranggen. Siswa lebih antusias dalam mengikuti pembelajaran yang dirancang dengan menarik, siswa akan senang mengikuti pembelajaran, aktif, kreatif dan terampil sehingga hasil belajar mereka dapat meningkat. Selain itu, guru juga akan lebih meningkatkan keterampilan dalam pembelajaran dengan menggunakan model yang inovatif.

Dari sekian banyak faktor yang mempengaruhi pembelajaran, maka salah satu faktor penentu yang sangat penting adalah guru. Dengan guru yang berkualitaslah makan penungkatan mutu pembelajaran dapat bertambah baik dan meningkat. Untuk bias menjadi guru yang berkualitas,salah satu yang dikuasai adalah kemampuan meneliti.

Oleh karena itu dari uraian diatas tentang guru, maka guru memegang peranan paling penting dalam pelaksanaan PTK. Hal ini dapat kita lihat dari prosedur peneliti kaji tindak. Bagaimana guru membuat perencanaan yang akan diterapkan dikelas untuk pertemuan yang akan dating agar menjadi perbaikan proses pembelajaran, mengadakan proses observasi dikelas yang diajarnya, kemudian melakukan apa yang direncanakan dan sesudah itu guru melakukan refleksi dari hasil pelaksanaan tindakan. Dari hasil refleksi yang dilakukan kemudian guru akan membuat perencanaan lagi untuk pertemuan berikutnya. Semua itu dapat dilakukan oleh guru.

Ada beberapa penelitian yang dilakukan baik berkenaan dengan model yang penulis angkat yaitu model pembelajaran kooperatif tipe NHT. Penelitian yang sudah dilaksanakan I Gede Budi Astrawan (2013) yang berjudul" Penerapan Model Kooperatif Tipe NHT dalam Meningkatkan Hasil Belajar Siswa pada Mata Pelajaran IPA di Kelas V SDN 3 Tonggolobibi"menunjukan Prosentase rata-rata nilai pada siklus I sebesar55,71 \%. Siklus II dan terbukti berhasil dengan peningkatan prestasi belajar yang sangat baik. Persentase ketuntasan 85,71 dari 28 siswa dengan nilai rata-rata testulis dari 55,71 menjadi 76,07 dan nilai rata-rata aktivitas siswa selamapembelajaran dari 66,66\% menjadi 89,58\%.

Penelitian yang dilakukan oleh Samsidar (2013) yang berjudul "Pengunaan Model Pembelajaran Kooperatif Tipe Number Head Together (NHT) untuk Meningkatkan Hasil Belajar Siswa pada Mata Pelajaran IPA Kelas IV SD DDI Siboang" menunjukkan adanya peningkatan hasil belajar pada siklus I di peroleh tingkat ketuntasan $56,6 \%$ dan daya serap klasikal $69,6 \%$, sedangkan pada siklus II di peroleh 
tingkat ketuntasan belajar 82,6\% dan daya serap klasikal 81,7\%. Aktivitas belajar siswa pada siklus I ratarata68,75\% menjadi $89,58 \%$ pada siklus II.

2.Rumusan Masalah

Rumusan masalah dalam penelitian ini adalah: Bagaimanakah peningkatan hasil belajar siswa, keterampilan guru, dan aktivitas siswa kelas III B SD Negeri Kebonbatur 02 Mranggen pada mata pelajaran IPA dengan menggunakan model kooperatif tipe NHT?

3.Tujuan Penelitian

Tujuan dalam penelitian ini adalah untuk mengetahui peningkatan hasil belajar siswa, keterampilan guru, dan aktivitas siswa kelas III B SD Negeri Kebonbatur 02 Mranggen pada mata pelajaran IPA dengan menggunakan model kooperatif tipe NHT.

\section{Metode}

Penelitian ini mengacu pada tahapan penelitian tindakan kelas, yang menggunakan beberapa siklus sampai peningkatan yang diharapkan tercapai. Setiap siklus terdiri dari 4 tahapan yaitu menyusun rancangan tindakan (planning). pelaksanaan tindakan (action), observasi/pengamatan (observing) dan melakukan refleksi (reflecting) dan seterusnya sampai perbaikan atau peningkatan yang diharapkan tercapai (indikator keberhasilan). Subyek penelitian ini adalah siswa kelas III B SD Negeri Kebonbatur 02 Mranggen pada tahun ajaran 2017/2018 sebanyak 34 siswa yang terdiri dari 18 siswa laki-laki dan 16 siswa perempuan. Selain siswa, subjek penelitian ini ialah guru kelas.

Penelitian dilaksanakan di SD Negeri Kebonbatur 02 Mranggen, dengan alamat Jl. Dongko Raya No. 1 Kecamatan Mranggen Kabupaten Demak. Alasan digunakan di SD Negeri Kebonbatur 02 Mranggen adalah nilai mata pelajaran IPA masih dibawah KKM, dan metode pembelajaran yang digunakan guru kelas masih menggunakan metode ceramah Variabel dalam penelitian ini adalah sebagai berikut: a. Hasil belajar siswa kelas III B SD Negeri Kebonbatur 02 Mranggen mata pelajaran IPA materi kenampakan permukaan bumi melalui model kooperatif tipe NHT, b. Keterampilan guru kelas III B SD Negeri Kebonbatur 02 Mranggen dalam muatan pembelajaran IPA materi kenampakan permukaan bumi melalui model kooperatif tipe NHT, dan c. Aktivitas siswa kelas III B SD Negeri Kebonbatur 02 Mranggen dalam muatan pembelajaran IPA materi kenampakan permukaan bumi melalui model kooperatif tipe NHT.

Teknik Pengumpulan Data yang digunakan antara lain: 1) Tes, tes digunakan untuk mengukur hasil belajar siswa materi kenampakan permukaan bumi setelah dilakukan tindakan, baik pada akhir siklus I dan siklus II. Jenis tes yang digunakan adalah tes tertulis dan bentuk tes yaitu pilihan ganda, 2) Observasi, bservasi digunakan untuk memperoleh data tentang performa guru dan aktivitas belajar siswa kelas III B SD Negeri Kebonbatur 02 Mranggen, dan c) Dokumentasi, digunakan sebagai bukti pelaksanaan pembelajaran dalam penelitian. Dokumentasi ini berupa daftar nama siswa kelas III B, daftar nilai siswa kelas III B, foto dan video aktivitas dalam kegiatan inti pembelajaran di kelas III B SD Negeri Kebonbatur 02 Mranggen.

\section{Hasil dan Pembahasan}

Berdasarkan hasil analisis menunjukkan bahwa penerapan model pembelajaran kooperatif tipe NHT (Numbered Head Together) dapat meningkatkan hasil belajar IPA siswa. Peningkatan Hasil Belajar siswa dari hasil Tes dari pra siklus I ke siklus II.

Tabel 1. Hasil Belajar Siswa pada Siklus I

\begin{tabular}{lccccc}
\hline \multirow{2}{*}{ Jumlah Siswa } & \multirow{2}{*}{ Rata-rata } & \multicolumn{2}{c}{ Ketuntasan Belajar } & \multicolumn{2}{c}{ Persentase Ketuntasan } \\
& & Tuntas & Tidak Tuntas & Tuntas & Tidak Tuntas \\
\hline 34 & 73,56 & 20 orang & 14 orang & $58,82 \%$ & $41,18 \%$ \\
\hline
\end{tabular}

\section{Deskripsi Pengamatan Keterampilan Guru}

Tabel 2. Rekapitulasi Nilai Keterampilan Guru Pada Siklus I

\begin{tabular}{cccc}
\hline \multirow{2}{*}{ Pertemuan } & \multicolumn{2}{c}{ Skor } & \multirow{2}{*}{ Nilai } \\
\cline { 2 - 3 } & Penilaian Guru I & Penilaian Guru II & \\
\hline 1 & 86 & 75 & 78,67 \\
2 & 88 & 81 & 83,33 \\
Nilai akhir keterampilan siklus I & & & 81 \\
\hline
\end{tabular}




\begin{tabular}{lc}
\hline Kategori & $\mathrm{AB}$ \\
\hline
\end{tabular}

\section{Deskripsi Aktivitas Belajar Siswa}

Tabel 3. Nilai Aktivitas Belajar Siswa Siklus I

\begin{tabular}{lcccc}
\hline \multirow{2}{*}{ Kode Siswa } & \multicolumn{2}{c}{ Pertemuan 1 } & \multicolumn{2}{c}{ Pertemuan 2 } \\
\cline { 2 - 5 } & Jumlah Skor & Nilai & Jumlah Skor & Nilai \\
\hline Jumlah & 370 & 2312,5 & 419 & 9425 \\
Persentase & \multicolumn{2}{c}{$68,01 \%$} & & $77,02 \%$ \\
Persentase Siklus I & & \multicolumn{2}{c}{$72,52 \%$} & \\
\hline
\end{tabular}

Gambaran mengenai peningkatan aktivitas belajar siswa, hasil belajar siswa, serta keterampilan guru pada siklus I dapat dilihat pada Tabel dan diagram berikut ini:

Tabel 4. Rekapitulasi Hasil Penelitian Siklus I

\begin{tabular}{lccc}
\hline \multicolumn{1}{c}{ Hasil Penelitian } & Nilai & Indikator & Keterangan \\
\hline Persentase aktivitas belajar siswa & $72,52 \%$ & $\geq 75 \%$ & Tidak tercapai \\
Rata-rata hasil belajar siswa & 73,56 & $\geq 75$ & Tidak tercapai \\
Persentase tuntas belajar klasikal & $58,82 \%$ & $\geq 75 \%$ & Tidak tercapai \\
Keterampilan guru & 81 & $\geq 71$ & Tercapai \\
\hline
\end{tabular}

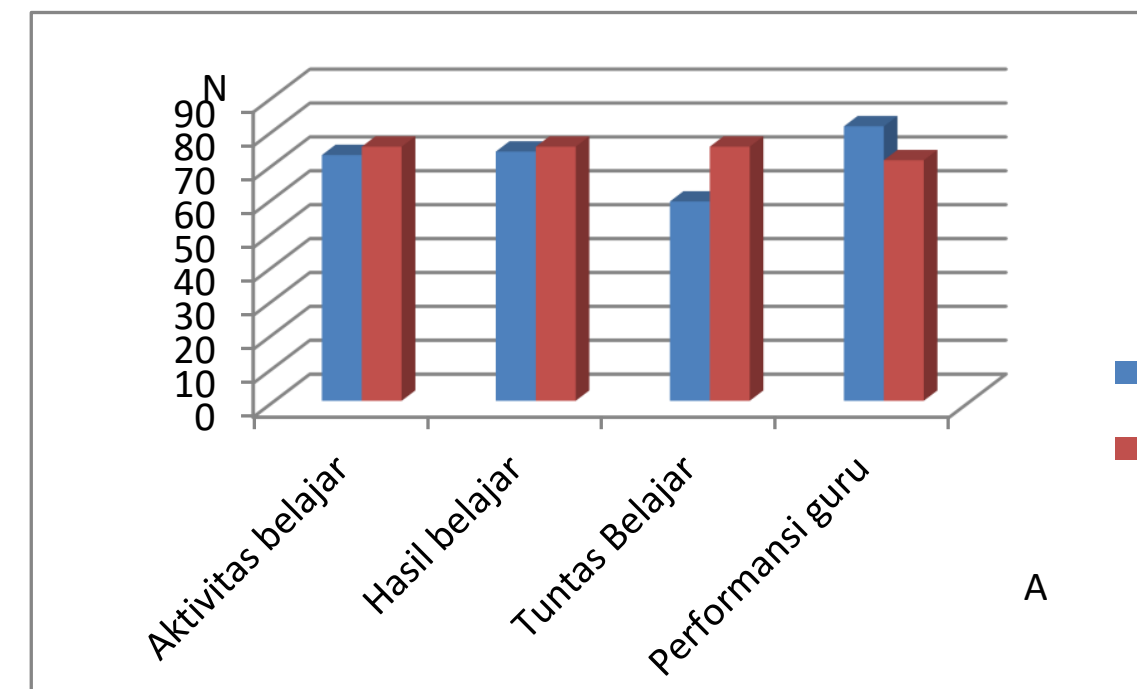

Gambar 1. aktivitas belajar siswa, hasil belajar siswa, serta keterampilan guru pada siklus I

\section{Deskripsi Data Tindakan Siklus II}

\section{Deskripsi Hasil Belajar Siswa}

Tabel 5. Hasil Belajar Siswa pada Siklus II

\begin{tabular}{lccc}
\hline & \multirow{2}{*}{ Keterangan } & Nilai & \multicolumn{2}{c}{ KKM } \\
\cline { 3 - 4 } & & Tuntas & Tidak Tuntas \\
\hline Jumlah Siswa & 2703 & & \\
\hline Jumlah Nilai & 79,50 & & \\
Rata-rata & & 32 & \\
Jumlah siswa tuntas belajar & & $94,12 \%$ & 2 \\
Persentase tuntas belajar & & & \\
Jumlah siswa tidak tuntas belajar & & & \\
\hline
\end{tabular}


\begin{tabular}{ll}
\hline Persentase tidak tuntas belajar & $5,88 \%$
\end{tabular}

Perbandingan hasil belajar siklus I dan siklus II dapat dilihat pada tabel dan diagram berikut ini:

Tabel 6. Perbandingan Hasil Belajar Siklus I dan Siklus II

\begin{tabular}{lcc}
\hline \multicolumn{1}{c}{ Keterangan } & \multicolumn{2}{c}{ Hasil Penelitian } \\
& Siklus I & Siklus II \\
\hline Rata-rata hasil belajar & 73,56 & 79,5 \\
Persentase tuntas belajar & $58,82 \%$ & $94,12 \%$ \\
\hline
\end{tabular}

\section{Deskripsi Pengamatan Keterampilan guru}

Tabel 7.Rekapitulasi Nilai Keterampilan Guru Pada Siklus II

\begin{tabular}{cccc}
\hline \multirow{2}{*}{ Pertemuan } & \multicolumn{2}{c}{ Skor } & Nilai \\
\cline { 2 - 3 } & Penilaian Guru I & Penilaian Guru II & 88,77 \\
2 & 90,12 & 88,1 & 93,35 \\
Nilai akhir keterampilan siklus II & 94,45 & 92,8 & 91,06 \\
Kategori & & & A \\
\hline
\end{tabular}

\section{Deskripsi Aktivitas Belajar Siswa}

Tabel 8. Nilai Aktivitas Belajar Siswa Siklus II

\begin{tabular}{lcccc}
\hline & \multirow{2}{*}{ Keterangan } & \multicolumn{2}{c}{ Pertemuan 1 } & \multicolumn{2}{c}{ Pertemuan 2 } \\
& Jumlah Skor & Nilai & Jumlah Skor & Nilai \\
\hline Jumlah & 434 & 2712,5 & 455 & 2844,75 \\
Persentase & \multicolumn{2}{c}{$79,78 \%$} & & $83,49 \%$ \\
Persentase Siklus II & \multicolumn{2}{c}{$81,71 \%$} & \\
\hline
\end{tabular}

Gambaran mengenai peningkatan aktivitas belajar siswa, hasil belajar siswa, serta keterampilan guru pada siklus II dapat dilihat pada tabel dan diagram berikut ini:

Tabel 10. Rekapitulasi Hasil Penelitian Siklus II

\begin{tabular}{lccc}
\hline \multicolumn{1}{c}{ Hasil Penelitian } & Nilai & Indikator & Keterangan \\
\hline Persentase aktivitas belajar siswa & $81,71 \%$ & $\geq 75 \%$ & Tercapai \\
Rata-rata hasil belajar siswa & 79,5 & $\geq 75$ & Tercapai \\
Persentase tuntas belajar klasikal & $94,12 \%$ & $\geq 75 \%$ & Tercapai \\
Keterampilan guru & 91,06 & $\geq 71$ & Tercapai \\
\hline
\end{tabular}




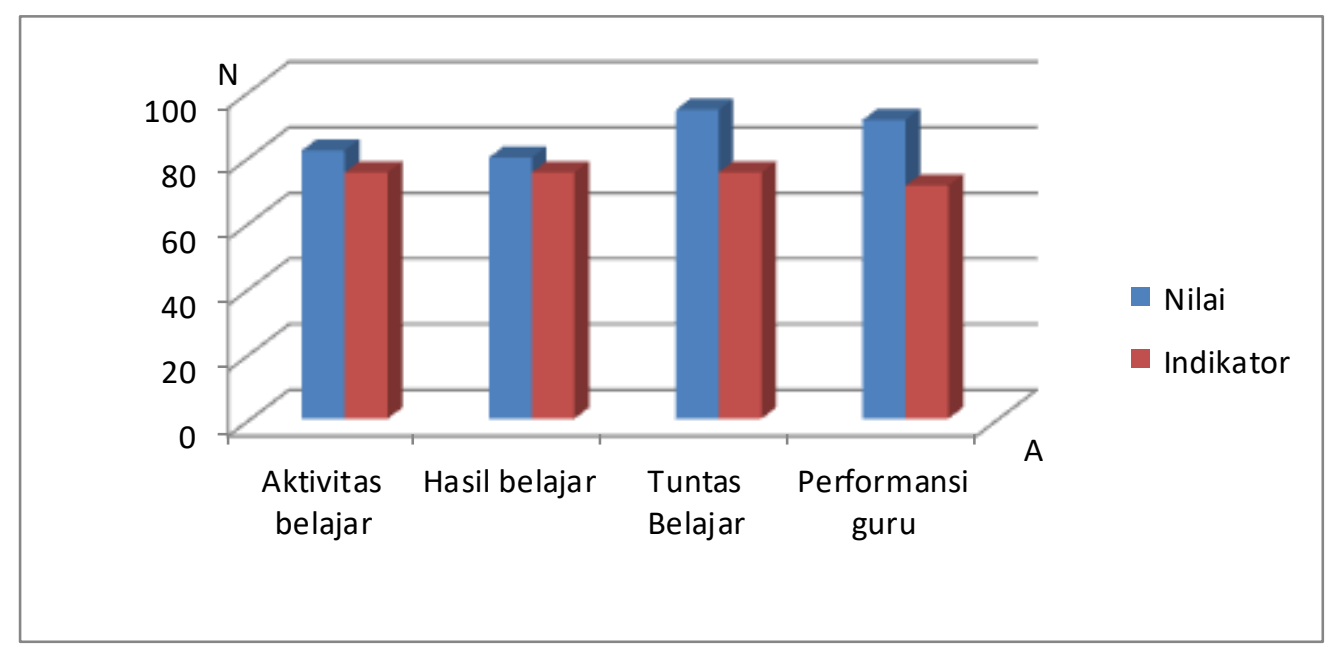

\section{Gambar 2. Diagram Hasil Penelitian Siklus II} ini:

Perbandingan hasil penelitian siklus I dan siklus II dapat dilihat pada tabel dan diagram berikut

Tabel 11. Rekapitulasi Hasil Penelitian Siklus II

\begin{tabular}{lcc}
\hline \multicolumn{1}{c}{ Keterangan } & \multicolumn{2}{c}{ Hasil Penelitian } \\
& Siklus I & Siklus II \\
\hline Persentase aktivitas belajar siswa & $72,52 \%$ & $81,71 \%$ \\
Rata-rata hasil belajar siswa & 73,56 & 79,5 \\
Persentase tuntas belajar klasikal & $58,82 \%$ & $94,12 \%$ \\
Keterampilan guru & 81 & 91,06 \\
\hline
\end{tabular}

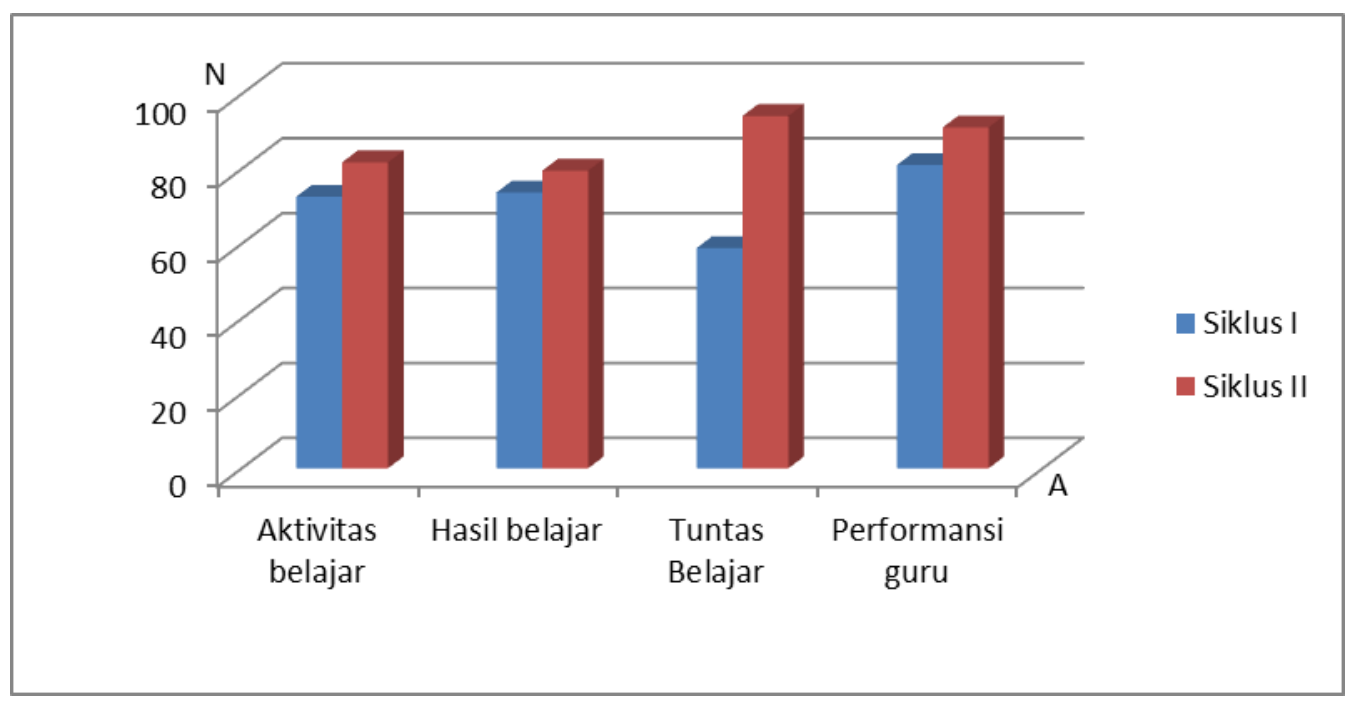

Gambar 3. Diagram Perbandingan Hasil Penelitian Siklus I dan Siklus II

Berdasarkan analisis data hasil pelaksanaan pembelajaran IPA materi kenampakan permukaan bumi melalui model kooperatif tipe NHT pada siswa kelas III.B SD Negeri Kebonbatur 02 Mranggen, dapat disimpulkan telah memenuhi semua aspek indikator keberhasilan.

Pelaksanaan penelitian tindakan kelas secara kolaboratif mengenai penerapan model kooperatif tipe NHT mata pelajaran IPA materi kenampakan permukaan bumi di kelas III.B SD Negeri Kebonbatur 02 Mranggen memperoleh hasil penelitian dengan pemaknaan sebagai berikut:

Berdasarkan hasil analisis data, diketahui bahwa aktivitas Pembelajaran IPA materi kenampakan permukaan bumi dengan menggunakan model kooperatif tipe NHT dengan penggunaan media tayang dan lembar kerja siswa mangalami peningkatan dari siklus I ke siklus II. Hal ini dapat dilihat dari ratarata hasil belajar siswa secara klasikal pada siklus I dengan persentase rata-rata $72,52 \%$ yang tergolong pada 
kategori sedang. Pada siklus II rata-rata meningkat menjadi persentase rata-rata sebesar 81,71\% yang berada dalam kategori tinggi. Seiring dengan peningkatan rata-rata hasil belajar siswa persentase ratarata pun ikut meningkat. Peningkatan persentase rata-rata dari siklus I ke siklus II sebesar 7,33\%.

Terjadinya peningkatan hasil belajar siswa kelas III semester ganjil pada mata pelajaran IPA disebabkan oleh pada pelaksanaan tindakan siklus II tidak lagi muncul kendala-kendala pada siklus I. Beberapa upaya yang dilakukan pada siklus II seperti merubah anggota kelompok belajar berdasarkan hasil tes siklus I. Hal ini dilakukan agar dalam satu kelompok terdiri dari siswa yang memiliki kemampuan merata. Membimbing siswa melatih keterampilan-keterampilan kooperatif saat melakukan diskusi dalam kelompok seperti saling berbagi tugas dan saling membantu antara anggota kelompok untuk memahami materi sehingga terjadi interaksi yang positif dan tidak ada yang diam atau pasif. Memberikan pujian dan penguatan juga dilakukan untuk menumbuhkan keberanian dan rasa percaya diri siswa untuk bertanya ataupun menjawab yang berkaitan dengan pembelajaran. Penguatan mempunyai peranan yang sangat penting dalam meningkatkan keefektifan kegiatan pembelajaran. Menurut Sri Anitah (2014) Penguatan adalah respon yang diberikan terhadap perilaku atau perbuatan yang dianggap baik, yang dapat membuat terulangnya atau meningkatnya perilaku/perbuatan yang dianggap baik tersebut.

Numbered Head Together (NHT) adalah salah satu pendekatan struktural, untuk melibatkan lebih banyak siswa dalam menelaah materi yang tercakup dalam suatu pembelajaran dan mengecek pemahaman siswa terhadap isi materi pembelajaran tersebut. Melalui kegiatan pembelajaran dengan menerapkan model kooperatif tipe NHT ini, siswa dituntut aktif dalam mengikuti kegiatan pembelajaran seperti: 1) mengamati penjelasan dan demonstrasi dalam materi media tayang dan LKS; 2) bersungguhsungguh mengerjakan tugas yang diberikan oleh guru; serta 3) mengajukan pertanyaan dan menjawab pertanyaan tentang materi pembelajaran baik kepada guru maupun kepada teman sebaya; dan 4) perhatian dan keantusiasan siswa dalam melaksanakan model kooperatif tipe NHT yaitu dengan mengikuti setiap langkah-langkah kegiatannya. Aktivitas-aktivitas tersebut telah dilaksanakan dengan baik, sehingga persentase aktivitas belajar siswa meningkat.

Dilihat dari hasil belajar siswa, pelajaran IPA materi kenampakan permukaan bumi juga mengalami peningkatan. Perubahan serta peningkatan hasil belajar dari siklus I ke siklus II tersebut dapat dijabarkan sebagai berikut: nilai rata-rata kelas dari 73,56 menjadi 79,5 dan ketuntasan klasikal dari 58,82\% menjadi $94,12 \%$. Hal tersebut terjadi karena siswa menanggapi positif tentang penerapan pembelajaran kooperatif tipe NHT, karena dengan model pembelajaran tersebut siswa dapat belajar bekerja sama menyelesaikan tugas yang diberikan oleh guru sehingga siswa yang merasa kurang memahami materi dapat bertanya kepada siswa yang lebih mengetahui. Dengan adanya kerjasama antara siswa maka bukan hanya akan terjadi interaksi antar siswa tetapi juga interaksi antar siswa dan guru, hal tersebut akan mendorong motivasi siswa untuk belajar dan meningkatkan hasil belajar siswa. Penelitian ini sejalan dengan penelitian yang dilakukan oleh Herawati (2014) menunjukkan bahwa dengan penerapan model pembelajaran kooperatif tipe NHT (Numbered Head Together) terdapat peningkatan motivasi belajar siswa dan hasil belajar siswa kelas VII C SMP Negeri 1 Semboro kabupaten Jember pada pokok bahasan pengelolaan lingkungan. Hasil penelitian ini sejalan dengan hasil penelitian Nursyamsi (2016) dengan hasil penelitian bahwa strategi pembelajaran memiliki efek pada retensi. Penelitian Suandewi (2017) dan Juliartini (2017) menunjukkan bahwa penerapan model pembelajaran kooperatif tipe Numbered Head Together (NHT) dapat meningkatkan hasil belajar IPA siswa. Supaya pembelajaran dapat berlangsung dengan baik dan maksimal, maka guru harus dapat merancang kegiatan pembelajaran dengan mempertimbangkan tujuan pembelajaran yang ingin dicapai, materi pembelajaran serta yang tidak kalah penting adalah sesuai dengan karakteristik yang dimiliki siswa.

\section{Simpulan dan Saran}

Simpulan yang dapat ditarik dari penelitian ini adalah : 1) Rata-rata nilai hasil belajar siswa yang diperoleh pada siklus I adalah 73,56 dengan persentase tuntas belajar klasikal sebesar 58,82\%. Pada siklus II, diperoleh rata-rata hasil belajar siswa sebesar 79,5 dengan persentase tuntas belajar klasikal sebesar 94,12\%. Dari hasil ini dapat disimpulkan bahwa terjadi peningkatan rata-rata hasil belajar siswa pada siklus I dan II sebesar 5,94 dan peningkatan persentase tuntas belajar klasikal sebesar 35,3\%, 2) Keterampilan guru dalam perencanaan pembelajaran dan pelaksanaan pembelajaran telah memperoleh nilai yang baik. Keterampilan guru pada siklus I sebesar 81 dan mengalami peningkatan pada siklus II sebesar 10,06 menjadi 91,06,3) Perolehan persentase aktivitas belajar siswa selama proses pembelajaran pada siklus I mencapai 72,52\% dan mengalami peningkatan pada siklus II menjadi 81,71\%. Dari hasil ini dapat disimpulkan bahwa terjadi peningkatan persentase aktivitas belajar siswa sebesar 9,29\% sehingga aktivitas belajar siswa telah memenuhi kriteria aktivitas belajar. 
Adapun saran yang adapt disampaikan dalam penelitian ini antara lain: a. Hendaknya guru dapat menerapkan model kooperatif tipe NHT dalam pembelajaran IPA untuk meningkatkan aktivitas dan hasil belajar siswa, b. Hendaknya guru dapat dapat merancang dan menerapkan suatu pembelajaran yang bukan hanya mengutamakan aspek kognitif saja, melainkan juga harus diiringi dengan aspek-aspek lainnya seperti afektif dan psikomotorik secara seimbang agar tujuan pembelajaran dapat tercapai secara optimal, dan c. Siswa, hendaknya lebih aktif dalam mengikuti semua fase dalam penerapan model kooperatif tipe NHT yang telah dirancang oleh guru dengan penuh perhatian dan rasa antusias.

\section{Daftar Rujukan}

Arikunto, Suharsimi, dkk. 2009. Penelitian Tindakan Kelas. Jakarta: Bumi Aksara.

Baharuddin dan Esa Nur Wahyuni. 2008. Teori Belajar dan Pembelajaran. Jogjakarta: Ar-Ruzz Media.

Hamdani. 2011. Komponen Pembelajaran. Jakarta: PT Rineka Cipta.

Herawati, Dera Dwi, Dwi Wahyuni, Jekti Prihatin. 2014. Penerapan Model Pembelajaran Kooperatif Tipe Nht (Numbered Head Together) Dengan Media Komik Pada Materi Pengelolaan Lingkungan Guna Meningkatkan Motivasi Dan Hasil Belajar (Siswa Kelas Vii C Smp Negeri 1 Semboro Jember). Pancaran, Vol. 3, No. 3, hal 73-82.

Iskandar, Srini M. 2001. Pendidikan Ilmu Pengetahuan Alarn (2nd Ed.). Bandung:CV. Maulana.

Juliartini, N. M. , N. W. Arini. 2017. Penerapan Model Pembelajaran Nht Untuk Meningkatkan Hasil Belajar Ipa Siswa Kelas III. J o u r n a l o f E d u c a t i o n A c t i o n R e s e a r c h Volume 1 Nomor 3.

Kurniasari. Fitri. 2014. Pengaruh Model Pembelajaran Numbered Head Together (Nht) Berbasis Realistik Terhadap Hasil Belajar SiswaJURNAL EDUTAMA Vol. 1 No. 2

Lie, Anita. 2005. Cooperative Learning Mempraktikkan Cooperative Learning di Ruang-ruang Kelas (4th Ed.). Jakarta: Grasindo.

Lorina, Pirade. (2012). Penerapan Model Pembelajaran Kooperatif Tipe Numbered Head Together Berbantuan Media Gambar untuk Meningkatkan Hasil Belajar Siswa Pada Mata Pelajaran IPA Di Kelas IV SDN No. 1 Tanjung Padang: Palu. Universitas Tadulako. Elementary School of Education EJournal, Media Publikasi Ilmiah Prodi PGSD Vol 2, Nomor 2.

Mayong Maman.(2016). The Implementation of Cooperative Learning Model 'Number Heads Together (NHT)' in Im proving the Students' Ability in Reading Comprehension. International Journal of Evaluation and Research in Education (IJERE) Vol.5, No.2, June 2016, pp. 174 180 ISSN: 2252-8822

Nursyamsi. (2016). The Effect Of Numbered Heads Together (NHT) Learning Strategy on the Retention of Senior High School Students In Muara Badak, East Kalimantan, Indonesia. European Journal of Education Student. Volume 2, Issue 5, 2016.

Slameto. 2003. Belajar dan Faktor faktor yang Mempengaruhinya. Jakarta:Rineka Cipta.

Suandewi, Ni Km. I Made.Citra Wibawa. (2017). Penerapan Model Pembelajaran Numbered Head Together Meningkatkan Hasil Belajar IPA siswa kelas IV SD No. 3 Kapal. Jurnal Ilmiah Sekolah Dasar. Vol.1 (1) pp 59-66.

Sukmayasa, I Made Hendra, I Wayan Lasmawan, Sariyasa.2013. Pengaruh Model Pembelajaran Kooperatif Tipe Nht Berbantuan Senam Otak Terhadap Keaktifan Dan Prestasi Belajar Matematika. e-Journal Program Pascasarjana Universitas Pendidikan Ganesha Jurusan Pendidikan Dasar (Volume 3

Suyatno. 2009. Menjelajah Pembelajaran Inovatif. Sidoarjo: Masmedia Buana Pustaka.

Suprijono, Agus. 2009. Cooperative Learning Teori dan Aplikasi Paikem.Yogyakarta: Pustaka Pelajar. 
Suyatno. 2009. Menjelajah Pembelajaran Inovatif. Sidoarjo: Masmedia Buana Pustaka.

Trianto. 2010. Mendesain Model Pembelajaran Inovatif-Progresif. Jakarta: Kencana.

Wahyuddin. 2017. Penerapan Model Pembelajaran Numbered Head Together (NHT) pada Siswa Kelas V SD Negeri 75 Ujungpero Kecamatan Sabbangparu Kabupaten Wajo. Suska Journal of Mathematics Education, Vol. 3, No. 1.

Yudiastuti, Gusti Ayu Kd, I Wayan Wiarta, Ketut Ardana. 2014. Pengaruh Model Pembelajaran Tipe Numbered Heads Together (Nht) Berbantuan Benda Konkret Terhadap Hasil Belajar Matematika Siswa Kelas V Gugus 1 Dalung Kecamatan Kuta Utara. Jurnal Mimbar PGSD Universitas Pendidikan Ganesha Jurusan PGSD Vol: 2 No: 1. 